\title{
Implementasi Nilai-Nilai Pancasila dalam Pembangunan Hukum Pidana Nasional
}

\author{
Andi Lala \\ Akamigas Indramayu, Indonesia \\ Email: andidoshukum@gmail.com
}

\begin{tabular}{l}
\hline \multicolumn{1}{c}{ Artikel info } \\
\hline Artikel history: \\
Diterima 05 Mei 2021 \\
Diterima dalam bentuk \\
revisi 10 Mei 2021 \\
Diterima dalam bentuk \\
revisi 17 Mei 2021
\end{tabular}

Keywords:

law; implementation of values; pancasila

\begin{abstract}
Indonesia is a state of law as stated in the 1945 Constitution Article 1 paragraph (3) which reads "The State of Indonesia is a State of law". Criminal Law is one of the existing laws in Indonesia, the regulation is contained in the Criminal Code (Book of Criminal Law) as one of the positive laws. The development of national criminal law should not be separated from the values contained in Pancasila, so that the track in law enforcement can also achieve justice based on Pancasila. This type of research is a type oflibrary research, which is based on library data or documentation that has been done. In accordance with the type of research, then in data collection the author uses the method of documentation or document study. Data sources in this writing are divided into primary data sources and secondary data sources. Based on the purpose of the research to be achieved, it begins by reviewing all the data that is available from various sources, namely documentation and data obtained from the library by reducing the data, namely the data obtained from the library. The values of Pancasila as the fundamental values of the Indonesian state are in fact a source of all legal sources in the Indonesian state. So that objectively it is a view of life, awareness, legal ideals, and noble moral ideals that include the psychological atmosphere, as well as the character of the Indonesian nation. The reform of Indonesian criminal law that internalizes the values of Pancasila must remain directed at the national goals that the Indonesian nation wants to achieve as an independent and sovereign country. The current Criminal Code is a legal product of the Dutch East Indies Colonial government, which needs to be adapted to the ideology of the Indonesian nation, namely Pancasila.
\end{abstract}

\footnotetext{
Abstrak

Indonesia merupakan negara hukum sebagaimana tercantum dalam UndangUndang Dasar 1945 Pasal 1 ayat (3) yang berbunyi "Negara Indonesia adalah Negara hukum“. Hukum Pidana adalah salah satu hukum yang ada di negara Indonesia, pengaturan terdapat dalam KUHP (Kitab Undang-Undang Hukum Pidana) sebagai salah satu hukum positif. Pembangunan hukum pidana nasional seyogyanya tidak lepas dari nilai-nilai yang terkandung dalam Pancasila, sehingga trek dalam penegakan hukum juga dapat mencapai keadilan berdasarkan Pancasila. Jenis penelitian ini merupakan jenis penelitian kepustakaan (library research), yang mendasarkan pada data-data kepustakaan atau dokumentasi yang pernah dilakukan. Sesuai dengan jenis penelitian, maka dalam pengumpulan data penulis menggunakan metode dokumentasi atau studi dokumen. Sumber data dalam penulisan ini terbagi menjadi sumber data primer dan sumber data sekunder. Berdasarkan pada tujuan penelitian yang ingin dicapai, maka dimulai dengan menelaah seluruh data yang sudah tersedia dari berbagai sumber yaitu dokumentasi dan data yang diperoleh dari pustaka dengan mengadakan reduksi data yaitu data-data yang diperoleh dari kepustakaan. Nilai-nilai Pancasila sebagai nilai fundamental negara Indonesia pada hakikatnya merupakan suatu sumber dari segala sumber hukum dalam Negara Indonesia. Sehingga secara objektif merupakan suatu pandangan
} 
Kata Kunci:

hokum; implementasi nilainilai; pancasila hidup, kesadaran, cita-cita hukum, serta cita-cita moral yang luhur yang meliputi suasana kejiwaan, serta watak bangsa Indonesia. Pembaharuan hukum pidana Indonesia yang menginternalisasi nilai-nilai Pancasila harus tetap diarahkan pada tujuan nasional yang ingin dicapai oleh bangsa Indonesia sebagai sebuah negara yang merdeka dan berdaulat. KUHP yang saat ini masih berlaku merupakan produk hukum pemerintah Kolonial Hindia Belanda, yang perlu disesuaikan dengan ideology bangsa Indonesia yaitu Pancasila.

\section{Pendahuluan}

Sejarah lahirnya pancasila berawal dari pra-kemerdekaan dimana banyak figur-figur negarawan bangsa Indonesia berfikir keras untuk menemukan kembali jati diri bangsanya. Salah satunya negarawan bangsa Indonesia Ir. Soekarno mengusulkan lima dasar Negara.

Pancasila merupakan khasanah budaya Indonesia karena nilai-nilai sudah ada sejak sejarah Indonesia yaitu pada masa kerajaan Kutai, kerajaan Sriwijaya dan kerajaan Majapahit. Nilai-nilai Pancasila yang sudah ada sejak sejarah Indonesia harus diterapkan terhadap pembangunan hukum yang ada di Indonesia (Materi Ajar Mata Kuliah Pendidikan Pancasila, 2013).

KUHP yang berlaku di Indonesia masih menggunakan KUHP/WvS (Wetboek van Strafrecht voor Nederlandsch Indie) peninggalan jaman penjajahan Belanda dan mulai diterapkan sejak 1 Januari 1918 (berdasarkan S.732.19150) dengan latar belakang filosofi individualisme dan liberalisme yang berbeda dengan pandangan dan konsep nilai kehidupan bangsa (Wahyuningsih, 2018).

Bangsa Indonesia sudah berhasil melakukan reformasi hukum (legal reform) terhadap konstitusi secara besar-besaran. Undang-undang Dasar Negara Negara Republik Indonesia Tahun 1945 (UUD NRI 1945) semula hanya mencakup 71 butir ketentuan, setelah empat kali amandemen, berisi 199 butir ketentuan. Perubahannya ini bukan hanya redaksional, melainkan perubahan pada paradigma pemikiran yang sangat mendasar. Legal reform, mempunyai makna idealnya terus berlanjut dengan pembentukan dan pembaruan hukum peninggalan penjajah Belanda, yaitu Kitab Undang-Undang Hukum Pidana, Kitab Undang-undang Hukum Perdata, dan Hukum Dagang sekaligus hukum acara dan sistem peradilannya sehingga bangsa Indonesia memiliki sistem hukum produk sendiri.

Bangsa Indonesia adalah bangsa yang telah merdeka, seharusnya memiliki hukum produk sendiri yang bersifat nasional untuk memenuhi kebutuhan hukum negara baru yaitu Hukum Nasional sesuai dengan cita-cita dan nilai-nilai yang terkandung dalam Pancasila. Pemerintah dan banyak perguruan tinggi telah mengadakan ragam kegiatan ilmiah yang berskala lokal maupun nasional guna merumuskan pembangunan hukum nasional. Para pakar hukum pun demikian, banyak yang telah mengusulkan profil hukum nasional, akan tetap hukun nasional masih menggunakan hukum Belanda. 


\section{Metode Penelitian}

Jenis penelitian ini merupakan jenis penelitian kepustakaan (library research), yang mendasarkan pada data-data kepustakaan atau dokumentasi yang pernah dilakukan. Studi kepustakaan (library research) adalah serangkaian kegiatan yang berkenaan dengan metode pengumpulan data pustaka, membaca dan mencatat serta mengolah bahan penelitiannya. Ia merupakan suatu penelitian yang memanfaatkan sumber perpustakaan untuk memperoleh data penelitiannya (Sugiyono, 2017).

Sesuai dengan jenis penelitian, maka dalam pengumpulan data penulis menggunakan metode dokumentasi atau studi dokumen. Dokumentasi, dari asal katanya dokumen, yang artinya barang-barang tertulis (Moleong, 2016). Dalam melaksanakan metode dokumentasi, penulis menyelidiki data-data atau dokumen-dokumen tertulis seperti buku-buku, artikel, jurnal, peraturan-peraturan, undang-undang, dan sebagainya.

Sumber data dalam penulisan ini terbagi menjadi sumber data primer dan sumber data sekunder. Sumber data primer yang dimaksud dalam penelitian ini adalah peraturan yang lebih spesifik yaitu Kitab Undang-undang Hukum Pidana yang kemudian dihubungkan dengan nilainilai Pancasila dalam pembangunan hukum pidana di Indonesia. Serta sumber data sekunder yaitu mengkaji Jurnal, majalah, artikel, serta bahan-bahan dari Internet yang ada kaitannya dengan penelitian ini.

Berdasarkan pada tujuan penelitian yang ingin dicapai, maka dimulai dengan menelaah seluruh data yang sudah tersedia dari berbagai sumber yaitu dokumentasi dan data yang diperoleh dari pustaka dengan mengadakan reduksi data yaitu data-data yang diperoleh dari kepustakaan yang dirangkum dengan memilih hal-hal yang pokok serta disusun lebih sistematis sehingga mudah dikendalikan, maka dalam hal ini penulis menggunakan analisa data kualitatif, dimana data dianalisa dengan metode deskriptif kualitatif yaitu suatu metode yang bertujuan untuk menggambarkan secara obyektif dalam rangka mengadakan perbaikan terhadap permasalahan yang dihadapi sekarang yaitu tentang urgensi penerapan nilai-nilai Pancasila dan Pasal-pasal yang terdapat di dalam KUHP dalam rangka mewujudkan pembangunan hukum pidana nasional.

\section{Hasil dan Pembahasan}

1. Pemahaman Sejarah dan Implementasi Nilai-Nilai Pancasila Dalam Pembangunan Hukum

Pancasila yang terdiri atas bagian-bagian yaitu sila-sila pancasila, setiap sila pada hakekatnya merupakan asas tersendiri, fungsi sendiri-sendiri dan tujuan tertentu, yaitu suatu masyarakat yang adil dan makmur berdasarkan pancasila.

Sila-sila pancasila yang merupakan sistem filsafah pada hakekatnya merupakan satu kesatuan organik. Antara sila-sila Pancasila itu saling berkaitan, saling mengkualifikasi. sila yang satu senantiasi dikualifikasikan oleh sila-sila lainya, maka pada hakekatnya pancasila merupakan sistem dalam pengertian bahwa bagian-bagian sila-silanya saling berhubungan secara erat sehingga membentuk suatu struktur yang menyeluruh.

Kenyataan pancasila yang demikian disebut sebagai kenyataan yang objektif, yaitu bahwa kenyataan itu ada pada pancasila itu sendiri terlepas dari suatu yang lain atau terlepas dari pengetahuan orang. Kenyataan objektif yang ada dan terlekat pada pancasila, sehingga pancasila sebagai suatu sistem bersifat khas dan berbeda dengan sistem-sistem falsafah yang 
lain. Hal ini secara ilmiah disebut sebagai filsafah secara objektif

Nilai-nilai Pancasila sebagai nilai fundamental negara Indonesia pada hakikatnya merupakan suatu sumber dari segala sumber hukum dalam Negara Indonesia. Sehingga secara objektif merupakan suatu pandangan hidup, kesadaran, cita-cita hukum, serta cita-cita moral yang luhur yang meliputi suasana kejiwaan, serta watak bangsa Indonesia. Padatanggal 18 Agustus 1945 telah dipadatkan dan diabstraksikan oleh para pendiri Negara menjadi lima Sila dan ditetapkan secara yuridis formal menjadi dasar filsafat Negara Republik Indonesia. Sebagaimnan ditetapkan dalam Ketetapan No. XX/MPRS/1966. Bahkan dasar fundamental moral yang dituangkan dari nilai-nilai Pancasila tersebut juga harus mendasari moral dalam kaitannya politik luar negeri Indonesia. Sehingga, hendaknya upaya perbaikan kondisi dan nasib bangsa ini didasarkan pada moralitas, terutama pada moral ketuhanan dan kemanusiaan dalam bingkai dasar Pancasila. Makna Nilai-Nilai Setiap Sila Pancasila Sila-sila Pancasila merupakan sesuatu system nilai, oleh karena itu pada hakikatnya merupakan suatu kesatuan yang sistematis dan hirarkis. Sehingga meskipun dijelaskan secara rinci dalam sila-sila, namun kesemuanya itu tidak dapat dilepaskan keterkaitanya satu sama lain.

Pancasila sebagai dasar fundamental serta ideologi bangsa merupakan hal yang penting dalam perjalanan hidup bangsa Indonesia. Pengertian ideologi berasal dari kata yunani yaitu iden yang berarti melihat, atau idea yang berarti raut muka, perawakan, gagasan buah pikiran dan kata logi yang berarti ajaran. Dengan demikian ideologi adalah ajaran atau ilmu tentang gagasan dan buah pikiran atau science des ideas. Menurut pendapat Harol H. Titus. Definisi dari ideologi adalah: Aterm used for any group of ideas concerning various political and aconomic issues and social philosophies often applied to asystematic scheme of ideas held by groups or classes, artinya suatu istilah yang digunakan untuk sekelompok cita-cita mengenai bebagai macam masalah politik ekonomi filsafat sosial yang seringdilaksanakan bagi suatu rencana yang sistematis tentang suatu cita-cita yang dijalankan oleh kelompok atau lapisan masyarakat (Adhayanto, 2015).

Bangsa Indonesia adalah bangsa yang telah merdeka pada tanggal 17 Agustus 1945, akan tetapi sebelum merdeka para tokoh dan cendekiawan membuat suatu konsepsi cita-cita suatu bangsa sebagai identitas bangsa. Para tokoh itu antara lain, Muh. Yamin, Prof. Dr. Soepomo dan Ir Soekarno.

Sejarah pembentukan Pancasila sebagai dasar Negara dimulai dari sebelum kemerdekaan bangsa Indonesia, dimulai sidang pertama BPUPKI yang dilaksanakan pada tanggal 29 Mei-1 Juni 1945, Muhammad Yamin menyampaikan rumusan Dasar Negara yang terdiri lima sila. Dilanjutkan Prof. Dr. Soepomo pada tanggal 30 Mei 1945 mengemukakan teori Negara yang terdiri tiga teori.Dan yang terakhir Ir Soekarno pada tanggal 1 Juni 1974 mengusulkan limadasar Negara.

Pancasila di Era Kemerdekaan pada tanggal 16 Agustus 1945 terjadi perundingan para tokoh guna menyusun teks proklamasi yang disusun oleh Ir.Soekarno,Drs Moh Hatta, dan Mr. Ahmad Soebardjo. Teks Proklamasi ditanda tangani oleh Ir.Soekarno dan Drs Moh Hatta atas nama bangsa Indonesia.

Pancasila di Era Orde Lama, terdapat dua pandangan yang pertama Pancasila sebagaimana dirumuskan dalam Piagam Jakarta sebagai dasar Negara dan kembalinya ke Undang-Undang Dasar 1945 tanpa cadangan artinya Pancasila yang dirumuskan dalam Pembukaan Undang-Undang Dasar yang disyahkan oleh PPKI tanggal 18 Agustus 1945 sebagai dasar Negara. 
Pancasila di Era Orde Baru, setelah lengsernya Ir.Soekarno sebagai presiden. Selanjutnya Jendral Soeharto memegang kendali di Negara Indonesia. Dalam era Orde Baru Pancasila oleh Jendral Soeharto dijadikan sebagai Political Force disamping sebagai kekuatan ritual. Begitu kuatnya Pancasila digunakan sebagai dasar Negara, maka pada 1 Juni 1967 mengatakan Pancasila sebagai pandangan hidup bangsa agar bangsa Indonesia tidak loyo.

Pancasila di Era Reformasi, diawali dengan hancurnya ekonomi yang dimulai dengan gerakan masyarakat yang dipelopori oleh mahasiswa. Dalam bidang politik terjadi disorientasi politik kebangsaan, seluruh aktivitas politik seolah-olah hanya tertuju pada kepentingan kelompok dan golongan. Lebih dari itu, aktivitas politiknya hanya sekedar merupakan lipido dominandi atas hasrat untuk berkuasa, bukannya sebagai suatu aktivitas memperjuangkan kepentingan nasional yang pada akhirnya menimbulkan carut marut kehidupan bernegara.

Berdasarkan atas kesepakatan, Pancasila menjadi dasar Negara Republik Indonesia secara normative tercantum dalam ketetapan MPR Nomor XVIII/MPR/1998 pasal 1 menyebutkan bahwa" Pancasila sebagaimana dimaksud dalam pembukaan UUU 1945 adalah dasar Negara dari Negara Republik Indonesia harus dilaksanakan secara konsisten dalam kehidupan bernegara".

Bapak Proklamator kita adalah Ir. Soekarno mengatakan"sejarah merupakan guru kehidupan". Arus sejarah memperlihatkan dengan nyata bahwa semua bangsa memerlukan suatu konsepsi dan cita-cita. Pentingnya cita-cita ideal sebagai landasan moralitas bagi kebesaran bangsa, hal ini diperkuat oleh para cendekiawan Amerika serikat John Gardner yang mengatakan "Tidak ada bangsa yang dapat mencapai kebesaran kecuali jika bangsa itu mempercayai sesuatu, dan sesuatu yang dipercayainya itu memiliki dimensi-dimensi moral guna menopang peradaban besar". Sejak pancasila ada dan sudah dijadikan dasar dan ideologi bangsa, maka Pancasila merupakan cerminan dari jiwa dan cita-cita hukum bangsa Indonesia tersebut merupakan norma dasar dalam penyelenggaraan bernegara dan menjadi sumber dari segala sumber hukum sekaligus sebagai cita-cita baik tertulis maupun tidak tertulis.

Keberadaan Pancasila terdapat pada Pembukaan UUD Negara Republik Indonesia tahun 1945, maka fungsi pokok Pancasila sebagai dasar Negara pada hakikatnya adalah sumber hukum atau sumbertertib hukum di Indonesia, sebagaimana tertuang dalam ketetapan MPRS No.XX/MPRS/1966 (Jo.Ketetapan MPR No.IX/MPR/1978). Hal ini mengandung konsekuensi yuridis yaitu bahwa seluruh peraturan perundang-undangan Republik Indonesia (Ketetapan MPR, Undang-Undang, Peraturan pemerintah, Keputusan Presiden dan Peraturan-peraturan yang dikeluarkan oleh Negara dan pemerintah Republik Indonesia) harus sejiwa dan sejalan dengan jiwa Pancasila.Ini berarti bahwa hubungan Pancasila dengan Pembukaan UUD NRI Tahun 1945 dapat dipahami sebagai hubungan yang bersifat formal dan material.

Dalam hubungan bersifat formal antara Pancasila dan Pembukaan UUD 1945 adalah sebagai rumusan Pancasila sebagai dasar Negara Republik Indonesia adalah sebagai mana tercantum dalam alinea keempat. Di dalam Pembukaan UUD NRI Tahun 1945 (Kaelan 2000;91) merupakan Pokok Kaidah Negara yang Fundamental sehingga terhadap tertib hukum Indonesia mempunyai dua macam kedudukan, yaitu: 1) sebagai dasarnya, karena pembukaan itulah yang memberikan faktor-faktor mutlak bagi adanya tertib hukum Indonesia; 2) memasukan dirinya di dalam tertib hukum tersebut sebagai tertib hukum tertinggi. Dalam hubungan Pancasila dengan Pembukaan UUD NRI Tahun 1945 secara 
material adalah menunjuk pada materi pokok atau isi Pembukaan yang tidak lain adalah Pancasila (Adhayanto, 2015).

Dilihat dari sejarah yang ada bahwa usaha pembaharuan hukum di Indonesia yang sudah dimulai sejak proklamasi kemerdekaan tanggal 17 Agustus 1945, melalui UUD N RI Tahun 1945, tidak dapat dilepaskan dari landasan dan sekaligus tujuan nasional yang ingin dicapai seperti dirumuskan dalam Pembukaan UUD NKRI Tahun 1945, khusus nya alinea keempat yaitu, "Kemudian dari pada itu untuk membentuk suatu Pemerintah Negara Indonesia yang melindungi segenap bangsa Indonesia dan seluruh tumpah darah Indonesia dan untuk memajukan kesejahteraan umum, mencerdaskan kehidupan bangsa, dan ikut melaksanakan ketertiban dunia yang berdasarkan kemerdekaan, perdamaian abadi dan keadilan sosial, maka disusunlah Kemerdekaan Kebangsaan Indonesia itu dalam suatu Undang-Undang Dasar Negara Indonesia, yang terbentuk dalam suatu susunan Negara Republik Indonesia yang berkedaulatan rakyat dengan berdasar kepada Ketuhanan Yang Maha Esa, Kemanusiaan yang adil dan beradab, Persatuan Indonesia dan Kerakyatan yang dipimpin oleh hikmat kebijaksanaan dalam Permusyawaratan/Perwakilan, serta dengan mewujudkan suatu Keadilan sosial bagi seluruh rakyat Indonesia (Erfandi, 2016).

Pembangunan hukum merupakan upaya membentuk hukum baru guna memperbarui hukum positif. Memperbarui artinya menggantikan hukum-hukum lama dengan hukum yang baru. Pembangunan hukum dalam konteks ini semakna dengan pembaharuan hukum. Sedangkan hukum nasional adalah hukum yang dibangun didasarkan pada konstitusi dan Pancasila sebagai dasar negara atau hukum yang dibangun di atas cita rasa dan rekayasa bangsa Indonesia. Pembangunan sistem hukum nasional harus mencakup pembangunan substansi (materi) hukum, struktur atau lembaga hukum juga kultur hukum.

Menurut Satjipto Rahardjo, bahwa pembangunan hukum memiliki dua arti. Pertama sebagai upaya untuk memperbaharui hukum positif (memodernisasi hukum), kedua sebagai usaha untuk menfungsionalkan hukum yakni dengan cara mengadakan perubahan sosial sesuai dengan kebutuhan masyarakat yang sedang membangun. Dalam arti, pembangunan hukum tidak terbatas pada kegiatan legislasi melainkan juga upaya menjadikan hukum sebagai alat rekayasa sosial.

Menurut Paton, hakikat pembangunan hukum adalah pembinaan hukum dan pembaharuan hukum. Arti pembinaan hukum adalah perawatan terhadap hukum-hukum yang telah ada, bukan menghancurkan, tetapi membiarkannya tumbuh berkembang. Sedangkan pembaharuan hukum adalah membentuk tatanan hukum yang baru (Sri Endah Wahyuningsih, 2013).

Hukum Nasional harus mengabdi kepada kepentingan nasional dan tercapainya kesejahteraan rakyat, keadilan dan ketertiban masyarakat Hukum Nasional sebagai perwujudan nilai-nilai yang terkandung dalam Pancasila.

Penerapan Pancasila yang sudah diterapkan jaman kerajaan dan pembentukan Pancasila sebagai dasar Negara sejak sebelum kemerdekaan.Pancasila sebagai dasar Negara dan sumber dari segala sumber hukum terdapat dalam Pembukaan Undang-Undang Dasar 1945 alinea keempat merupakan sumber tertib hukum tertinggi.

Norma yang ada dalam masyarakat atau negara selalu merupakan suatu susunan yang bertingkat, seperti suatu piramida. Menurut Adolf Merkel dan Hans Kelsen, setiap kaidah hukum merupakan suatu susunan daripada kaedah-kaedah (stufenbau des Recht). Dalam 
"stufentheorie"-nya Hans Kelsen mengemukakan bahwa dipuncak "Stufenbau" terdapat kaedah dasar dari suatu tata hukum nasional yang merupakan suatu kaedah fundamental. Kaedah dasar tersebut disebut "groundnorm" yang merupakan asas-asas hukum yang bersifat abstrak, bersifat umum dan hipotetis (Ranggawidjaja, 1998).

Menurut Hans Nawiasky, dalam suatu negara yang merupakan kesatuan tatanan hukum, terdapat suatu kaidah tertinggi, yang kedudukannya lebih tinggi dari undang-undang dasar. Berdasarkan kaidah yang lebih tinggi inilah undang-undang dasar dibentuk. Kaidah tertinggi dalam kesatuan tatanan hukum dalam negara itu disebut dengan staatsfundamentalnorm, yang untuk bangsa Indonesia berupa Pancasila. Hakikat suatu staatsfundamentalnorm adalah syarat bagi berlakunya suatu undang-undang dasar karena lahir terlebih dahulu dan merupakan akar langsung pada kehendak sejarah suatu bangsa serta keputusan bersama yang diambil oleh bangsa (Astim, 2006).

Konsekuensi logis dari diletakkannya Pancasila sebagai ground norm-nya bangsa Indonesia tentunya harus dapat diimplementasikan dalam setiap aspek kehidupan bermasyarakat, berbangsa dan bernegara. Pancasila harus dijadikan "way of life" dalam diri setiap masyarakat Indonesia. Setiap aspek kehidupan baik ekonomi, sosial, budaya, maupun hukum harus senantiasa berlandaskan kepada nilai-nilai yang terkandung dalam setiap sila yang ada di dalam Pancasila.

2. Tindak Lanjut Implementasi Nilai-Nilai Pancasila dalam Pembangunan Hukum Pidana Nasional

Pancasila sebagai suatu sistem filsafat pada hakekatnya juga merupakan suatu sistem pengetahuan. Dalam kehidupan sehari-hari pancasila merupakan pedoman atau dasar bagi bangsa Indonesia dalam memandang realitas alam semesta, manusia, masyarakat, bangsa dan negara tentang makna hidup serta sebagai dasar manusia dalam menyelesaikan masalah yang terjadi dalam hidup dan kehidupan. Pancasila dalam pengertian yang demikian ini telah menjadi suatiu sistem cita-cita atau keyakinan-keyakinan yang telah menyangkut praksis karena dijaidka landasn hidup manusia atau suatu kelompok masyarakat dalam berbagai bidang kehidupan masyarakat. Hal ini berarti filsafat telah menjelma menjadi ideologi (Abdulgani, 2007).

Sebagai suatu ideologi maka pancasila memiliki 3 unsur pokok agar dapat menarik loyalitas dari pendukungnya yang pertama adalah Logos yaitu rasionalitas atau penalaran, Pathos yaitu penghayatanya dan ethos yaitu kesusilaannya (Widodo, 2013).

Sebagai suatu sitem filsafat atau ideologi maka pancasila harus memiliki unsur rasional terutama dalam kedudukannya sebgai suatu sistem pengetahuan.Terdapat tiga persoalan dalam etimalogi diantaranya, tentang sumber pengetahuan manusia, tentang teori kebenaran pengetahuan manusia, dan watak pengetahuan manusia (Hadhi, 2005).

Berikutnya tentang susunan pancasila sebagai suatu sistem pengetahuan sebagai suatu sistem pengetahuan pancasila memiliki susunan yang bersifat formal logis baik dalam arti susunan pancasila maupun isi arti sila-sila pancasila. Susunan kesatuan sila-sila pancasila adalah bersifat hirarkis dan berbentuk piramidal.

Usaha pembaharuan hukum pidana Indonesia yang menginternalisasi nilai-nilai Pancasila harus tetap diarahkan pada tujuan nasional yang ingin dicapai oleh bangsa Indonesia sebagai sebuah negara yang merdeka dan berdaulat. KUHP yang saat ini masih berlaku merupakan produkhukum pemerintah Kolonial Hindia Belanda, yang perlu disesuaikan dengan ideology 
bangsa Indonesia yaitu Pancasila.

Pembangunan hukum nasional harus diarahkan untuk terwujudnya system hukum nasional yang mengabdi kepada kepentingan nasional yang materinya bersumber pada cara pandang dan keyakinan bangsa Indonesia. Demikian juga terhadap persoalan baru yang harus direspon oleh kebutuhan hukum yang dibutuhkan untuk mendukung tugas umum pemerintahan dan memajukan kepentingan nasional.

Untuk melaksanakan program pembangunan hukum terdapat beberapa sendi utama yang dijadikan acuan dalam pembangunan system Hukum Nasional:

1. Sendi Negara berdasarkan konstitusi dan Negara berdasarkan atas hukum.

2. Sendi kerayatan dan demokrasi

3. Sendi kesejahteraan social

Sendi kesejahteraan social berarti system hukum nasional dibangun untuk mewujudkan citacita kesejahteraan dan keadilan sosial. Ini berarti pula bahwa penentuan dan pembentukan subtansi hukum harus dapat mewujudkan keadilan.

Pembangunan hukum pidana Nasional diharapkan sesuai dengan nilai-nilai kepribadian Pancasila, akan tetapi dalam melakukan perkembangan hukum yang bersifat universal demi ketertiban hukum antar bangsa di era globalisasi yang bersifat multi dimensional. Tujuan nasional (national goals) merupakan garis kebijakan umum yang menjadi landasan dan sekaligus tujuan pencapaian politik hukum di Indonesia. Tujuan tersebut juga menjadi landasan dan tujuan dari setiap usaha pembaruan hukum, termasuk pembaruan hukum pidana Indonesia.

Tujuan dari politik hukum pidana maka pemidanaan harus diarahkan kepada perlindungan masyarakat dari kejahatan serta keseimbangan dan keselarasan hidup dalam masyarakat dengan memperhatikan kepentingan-kepentingan masyarakat/negara, korban dan pelaku. Dengan demikian, ada dua tujuan yang ingin dicapai oleh hukum pidana dan pidana yaitu pertama "perlindungan masyarakat" dan "kesejahteraan masyarakat". Kedua tujuan tersebut sebagai batu landasan (acornerstone) dari hukum pidana dan pembaruan hukum pidana. Selain itu terdapat pula tujuan ikut serta menciptakan ketertiban dunia sehubungan dengan perkembangan zaman,bahwa kedua istilah inipun sering dipadatkan dalam satu istilah saja, yaitu "social defence", karena di dalam istilah "perlindungan masyarakat" sudah tercakup juga "kesejahteraan masyarakat".

Pembaharuan hukum pidana pasca kemerdekaan, sejatinya sudah dimulai dengan diundangkannya Undang-Undang Nomor 1 Tahun 1946 yang diumumkan tanggal 26 Februari 1946 tentang peraturan hukum pidana. Dalam Pasal 5 menegaskan Peraturan hukum pidana, yang seluruhnya atau sebagian sekarang tidak dapat dijalankan, atau bertentangan dengan kedudukan Republik Indonesia sebagai negara merdeka, atau tidak mempunyai arti lagi, harus dianggap seluruh atau sebagian sementara tidak berlaku".Bertitiktolakpadatujuan “perlindungan masyarakat" (social defence), maka tujuan penegakan hukum pidana dapat dibedakan menjadi: (a) perlindungan masyarakat dari perbuatan anti sosial yang merugikan dan membahayakan masyarakat, maka tujuan pemidanaannya adalah mencegah dan menanggulangi kejahatan, (b) perlindungan masyarakat dari sifat berbahayanya seseorang, maka tujuan pemidanaannya adalah memperbaiki pelaku kejahatan atau berusaha mengubah dan mempengaruhi tingkah lakunya agar kembali patuh pada hukum dan menjadi warga masyarakat yang baik dan berguna, (c) perlindungan masyarakat dari penyalahgunaan sanksi atau reaksi dari penegak hukum atau warga masyarakat pada umumnya, maka tujuan pemidanaannya 
adalah untuk mencegah terjadinya perlakuan atau tindakan sewenangwenang di luar hukum, (d) perlindungan masyarakat dari gangguan keseimbangan atau keselarasan berbagai kepentingan dan nilai akibat dari adanya kejahatan, maka penegakan hukum pidana harus dapat menyelesaikan konflik yang ditimbulkan oleh tindak pidana, dapat memulihkan keseimbangan dan mendatangkan rasa damai dalam masyarakat. Perlindungan masyarakat dalam hal ini mencakup pula secara khusus (Kittichaisaree, 2001:3).

Perkembangan hukum pidana diluar KUHP tersebut semakin banyak dan ada kecenderungan untuk meninggalkan kaedah atau prinsip-prinsip hukum pidana yang dimuat dalam Ketentuan Umum Hukum Pidana (Buku I KUHP). Kencenderungan ini mengarah pada upaya kriminalisasi norma. Perkembangan pengaturan aspek kriminalisasi baru ini diakibatkan oleh: (a) adanya tuntutan masyarakat terhadap kepentingan hukum baru yang harus dilindungi hukum pidana, (b) kebutuhan bidang hukum lain (hukum perdata dan hukum administrasi/hukum tatausaha negara) yang membutuhkan sanksi hukum pidana untuk memperkuat norma-norma dan nilai-nilainya, dan (c) adaptasi terhadap kemerdekaan dan proses demokratisasi.

Harmonisasi terhadap perkembangan internasional dalam bentuk konvensi baik yang sudah atau belum diratifikasi. Sebaliknya adapula yang berupa dekriminalisasi atau depenalisasi. Undang-undang yang memuat ketentuan hukum pidana baik berupa penghapusan norma hukum pidana, mengubah norma hukum pidana, maupun menambah norma hukum pidana baru dalam KUHP, serta undang-undang yang mengatur norma hukum pidana di luar KUHP baik yang mengatur kaedah hukum yang menyimpang dari aturan umum KUHP maupun yang tidak

Berdasarkan pencermatan terhadap perkembangan hukum pidana tersebut, menunjukkan bahwa KUHP atau Wetboek van Strafrecht voor Nederlandsch-Indie (S.1915 No. 732) yang dinyatakan berlaku di Indonesia berdasarkan UU. Nomor 1 Tahun 1946 Jo.UU.Nomor 73 Tahun 1958 baik pada bagian Ketentuan Umum ("general rules"/algemmene deel) yang dimuat dalam Buku I KUHP maupun bagian rumusan Kejahatan (misdrijven) yang dimuat dalam Buku II KUHP, dan rumusan Pelanggaran (overtredingen) yang dimuat dalam Buku III KUHP, tidak lagi dijadikan rujukan utama dalam merumuskan kebijakan legislasi dalam bidang hukum pidana. Dalam kontek sinilah seakan-akan terjadi dualism system hukum pidana, yaitu sistem hukum pidana yang dibangun berdasarkan KUHP, dan sistem hukum pidana yang dibangun berdasarkan undang-undang yang tersebar diluar KUHP. Untuk itu perlu ada ikhtiar sesuai kaidah hukum untuk memasukkan nilai-nilai pancasila dalam rancangan undang-undang KUHP yang baru.

Berdasarkan pemaparan di atas, maka perlu dikaji secara lebih mendalam mengenai bagaimana Sejarah Implementasi Nilai Pancasila dalam Hukum Indonesia, dan bagaimana landasan penerapan sistem hukum pidana di Indonesia. Dengan harapan agar mampu memberikan kontribusi pemikiran secara komprehensif mengenai sejarah dan nilai-nilai Pancasila yang sangatlah relevan untuk dimasukkan sebagai ide fundamental dalam sistem hukum di Indonesia. Sekaligus dapat menguraikan implementasi nilai-nilai Pancasila terutama dalam sistem hukum pidana Indonesia.

Sesungguhnya, dalam alenia keempat pada Pembukaan UUD NKRI sudah memuat ketentuan dari setiap sila Pancasila yang selanjutnya diturunkan didalam Pasal-pasal didalam batang tubuh. Dengan kata lain, pasal-pasal yang terkandung didalam batang tubuh sudah barang tentumembawa semangat yang terkandung didalam materi pembukaan UUD 1945 itu 
sendiri.

Rumusan dasar filosofis negara atau ideologi negara yang terkandung oleh Pembukaan UUD 1945 adalah Pancasila. Rumusan Pancasila tersebut dapat pula disebut sebagai rumusan dasar dari cita hukum (rechtsidee) negara Republik Indonesia. Sebagai cita negara, tentunya ia harus dirumuskan berdasarkan cita yang hidup di dalam masyarakat (volksgeemenschapside) yang telah ada sebelum negara ini didirikan (Hamzah Halim dan Kemal Redindo Syahrul Putera, 2009).

Sebagaimana diketahui cita hukum selain mempunyai fungsi konstitutif yang menentukan dasar suatu tata hukum, yang tanpa itu suatu tata hukum kehilangan arti dan maknanya sebagai hukum, juga mempunyai fungsi regulatif yang menentukan apakah suatu hukum positif itu adil atau tidak adil. Dengan demikian juga, dalam hal Pancasila merupakan cita hukum, maka nilai-nilai yang terdapat di dalam Pancasila mempunyai fungsi konstitutif yang menentukan apakah tata hukum Indonesia merupakan tata hukum yang benar, dan disamping itu mempunyai fungsi regulatif yang menentukan apakah hukum positif yang berlaku di Indonesia merupakan hukum yang adil atau tidak (Hamzah Halim dan Kemal Redindo Syahrul Putera, 2009).

Terkait dengan hal ini sangat relevan dengan teori hierarchy of norms yang menyatakan bahwa setiap norma hukum dianggap sah karena ia diciptakan/dibuat dengan cara yang ditentukan oleh norma lain. Jadi, hubungan hirarkis norma-norma hukum tersebut menggambarkan bahwa suatu norma hukum yang lebih tinggi menjadi dasar keabsahan norma yang dibentuknya (norma yang lebih rendah). Hubungan antar norma yang mengatur pembentukkan norma yang lain dapat dipersentasikan sebagai suatu hubungan super dan subordinasi. Sebuah norma yang menentukan pembentukkan norma yang lain adalah norma yang superior, sedangkan norma yang diciptakan menurut hubungan ini adalah norma yang inferior.

Dalam konteks ini, materi muatan setiap peraturan perundang-undangan, peran dan aspek filosofis, sosiologis, dan politis sangat urgen dan strategis untuk melengkapi konsep Hans Kelsen tersebut (Hamzah Halim dan Kemal Redindo Syahrul Putera, 2009).

Sebagai negara berdasarkan atas hukum (rechstaat) yang modern berdasarkan ketentuan dalam UUD 1945, Indonesia secara sadar berkehendak, berusaha, dan berupaya untuk menggapai tujuan-tujuannya.Untuk itu, perlu dilakukan modifikasi-modifikasi dalam kehidupan dan penghidupan masyarakat serta rakyatnya. Pengubahan-pengubahan sosial itu dilakukan dengan penyelenggaraan pembangunan, rencana-rencana, hukum yang melandasinya, peraturan-peraturan kebijakan yang menunjang pelaksanaannya (Hamzah Halim dan Kemal Redindo Syahrul Putera, 2009).

Dalam konteks hukum, khususnya dalam pembentukkan peraturan perundang-undangan, Pancasila semestinya diletakkan dalam wilayah sumber hukum materiil dari pembentukkan peraturan perundang-undangan. Hal ini diperkuat dengan amanat dari Pasal 2 Undang-Undang Nomor 12 Tahun 2011 Tentang Pembentukkan Peraturan Perundang-Undangan yang menyebutkan bahwa "Pancasila merupakan sumber segala sumber hukum Negara". Penempatan Pancasila sebagai sumber dari segala sumber hukum negara adalah sesuai dengan Pembukaan Undang-Undang Dasar Negara Republik Indonesia Tahun 1945, dimana Pancasila ditempatkan sebagai dasar dan ideologi negara serta sekaligus dasar filosofis bangsa dan negara sehingga setiap materi muatan peraturan perundang-undangan tidak boleh bertentangan 
dengan nilai-nilai yang terkandung dalam Pancasila.

Produk hukum yang dibuat sesungguhnya merupakan interprestasi dari kehendak masyarakat itu sendiri. Mengutip pendapat Eugen Erlich, yang menyebutkan hukum sebagai living law-nya masyarakat atau dengan menyetir pendapatnya Von Savigny yang menyebutkan bahwa hukum itu sebagai volksgeist- masyarakat.Selain itu juga, pentingnya mengkaji hukum dari aspek sosiologis menurut Soerjono Soekanto dikarenakan salah satu faktor yang mempengaruhi proses penegakkan hukum itu adalah masyarakat itu sendiri. Sehingga dinilai sangat perlulah untuk melakukan kajian kemasyarakatan atau kondisi terkini dimasyarakat terhadap upaya penyusunan setiap rancangan peraturan perundang-undangan.Hal ini dikarenakan pembentukkan peraturan perundang-undangan yang baik dan mudah diterapkan di masyarakat merupakan salah satu pilar utama bagi penyelenggaraan suatu Negara.

Hal-hal di atas sebenarnya telah diperkuat di dalam ketentuan Pasal 6 Undang-Undang Nomor 12 Tahun 2011 Tentang Pembentukkan Peraturan Perundang-Undangan yang menyebutkan bahwa materi muatan Peraturan Perundang-undangan harus mencerminkan asas: pengayoman, kemanusiaan, kebangsaan, kekeluargaan, kenusantaraan, bhinneka tunggal ika, keadilan, kesamaan kedudukan dalam hukum dan pemerintahan, ketertiban dan kepastian hukum; dan/atau keseimbangan, keserasian, dan keselarasan yang notabenenya kesemua asas tersebut mencerminkan setiap butir pada sila-sila yang terkandung di dalamditerima oleh setiap lapisan masyarakat, karena sesungguhnya nilai-nilai tersebut merupakan nilai-nilai yang hidup, tumbuh dan berkembang dimasyarakat itu sendiri.

pembangunan sistem hukum Indonesia seharusnya mengarah kepada cita negara (staatsidee) Indonesia yang sejauh mungkin harus dibangun secara khas dalam arti tidak meniru paham individualisme-liberalisme yang justru telah melahirkan kolonialisme dan imperialisme yang harus ditentang, ataupun paham kolektivisme ekstrim seperti yang diperlihatkan dalam praktek di lingkungan negara-negara sosialis-komunis. Dengan kata lain, semangat yang melandasi pemikiran para pendiri Republik Indonesia adalah semangat sintesis, semangat untuk melakukan kombinasi atau semangat untuk menciptakan suatu paham baru, yakni paham yang berlandaskan Pancasila (Huda, 1999).

Pancasila secara utuh sebagai suatu "national guidelines", dan "national standard, norm and principles", yang pada sudut pandang lain Pancasila pula, berguna sebagai margin of appreciation dijadikan bahan acuan dan pedoman bagi upaya-upaya membentuk regulasi yang tetap berpijak pada tatanan nilai-nilai pandangan hidup bangsanya.Sudah sepatutnya produk perundang-undangan yang dibentuk harus mampu mengharmonisasikan antara kepentingan nilai-nilai nasional melalui ideologinegara sebagai sumber dari segala sumber hukum yang diberlakukan. Hingga akhirnya mampu mengakomodir kepentingan global dengan mengedepankan atau tidak mengesampingkan nilai-nilai kearifan lokal yang dikandung dalam nilai-nilai Pancasila. Dengan demikian Pancasila tetap memegang peranan penting dalam penyusunan norma hukum. Bila hal ini terabaikan maka dapat menyebabkan semua upaya untuk memastikan perlindungan hak-hak ekonomi rakyat dan terjaminnya demokrasi ekonomi, menemui jalan buntu. Dan amanat kosntitusi UUD 1845 pun telah terabaikan.

\section{Kesimpulan}

Pembangunan hukum nasional harus diarahkan untuk terwujudnya system hukum nasional yang mengabdi kepada kepentingan nasional yang materinya bersumber pada 
cara pandang dan keyakinan bangsa Indonesia. Demikian juga terhadap persoalan baru yang harus direspon oleh kebutuhan hukum yang dibutuhkan untuk mendukung tugas umum pemerintahan dan memajukan kepentingannasional.

Presiden Soekarno pernah mengatakan "sejarah merupakan guru kehidupan". Arus sejarah memperlihatkan dengan nyata bahwa semua bangsa memerlukan suatu konsepsi dan cita-cita..Pentingnya cita-cita ideal sebagai landasan moralitas bagi kebesaran bangsa, hal ini diperkuat oleh para cendekiawan Amerika serikat John Gardner yang mengatakan "tidak ada bangsa yang dapat mencapai kebesaran kecuali jika bangsa itu mempercayai sesuatu, dan sesuatu yang dipercayainya itu memiliki dimensi-dimensi moral guna menopang peradaban besar". Sejak pancasila ada dan sudah dijadikan dasar dan ideologi bangsa, maka Pancasila merupakan cerminan dari jiwa dan cita-cita hukum bangsa Indonesia tersebut merupakan norma dasar dalam penyelenggaraan bernegara dan menjadi sumber dari segala sumber hukum sekaligus sebagai cita-cita baik tertulis maupun tidak tertulis.

Maka dapat ditarik kesimpulan bahwa pembangunan hukum nasional harus diarahkan kepada kepentingan nasional demi tercapainya kesejahteraan rakyat, keadilan dan ketertiban masyarakat. Dalam pembangunan hukum dalam arti membangun hukum lama menjadi yang baru harus sesuai nilai-nilai dasar dan ideologi bangsa Indonesia yaitu Pancasila.

\section{Bibliografi}

Abdulgani, R. (2007). Pengembangan pancasila di Indonesia. Yayasan Idayu.

Adhayanto, O. (2015). Implementasi Nilai-Nilai Pancasila Sebagai Dasar Negara Dalam Pembentukkan Peraturan Perundang-Undangan. Jurnal Ilmu Hukum, 6(2), 166-174.

Astim, R. (2006). Teori Konstitusi. Bandung: Yapemdo.

Erfandi, E. (2016). Implementasi Nilai-Nilai Pancasila dalam Pembangunan Sistem Hukum Pidana di Indonesia. Jurnal Ilmiah Pendidikan Pancasila Dan Kewarganegaraan, 1(1), 23-32. 
Hadhi, M. (2005). Negara Islam Indonesia: Fakta Sejarah dan Perkembangannya. Fakultas Hukum Universitas Indonesia.

Hamzah Halim dan Kemal Redindo Syahrul Putera. (2009). Cara Praktis Menyusun \& Merancang Peraturan Daerah,. Kencana.

Huda, N. (1999). Hukum Tata Negara Kajian Teoritis dan Yuridis Terhadap Konstitusi Indonesia. PSH FH UII, Yogyakarta.

Materi Ajar Mata Kuliah Pendidikan Pancasila. (2013). Direktorat Pembelajaran dan Kemahasiswaan Direktorat Jenderal Pendidikan Tinggi Kementerian Pendidikan dan Kebudayaan.

Moleong, L. J. (20016). Metodologi penelitian kualitatif edisi revisi. Bandung: PT Remaja Rosdakarya, 103.

Ranggawidjaja, R. (1998). Pengantar Ilmu Perundang-Undangan Indonesia. Bandung: Mandar Maju.

Sri Endah Wahyuningsih. (2013). Perbandingan Hukum Pidana dari Perspektif Religious Law System.

Sugiyono. (2017). Metode Penelitian Kuantitatif Kualitatif dan R\&D. CV. Alfabeta, Bandung.

Wahyuningsih, S. E. (2018). Model Pengembangan Asas Hukum Pidana Dalam KUHP Berbasis Nilai-Nilai Ketuhanan Yang Maha Esa. Fastindo, Semarang.

Widodo, S. (2013). Pespektif Pancasila dalam Kehidupan Sosial dan Politik”, dalam, Sudjito (Tim Peny), Strategi Pembudayaan Nilai-nilaiPancasila dalam Menguatkan Semangat Ke-Indonesia-an,. Penerbit Ombak dan Penerbit Pusat Studi Pancasila UGM. 